\title{
DAMPAK PEMBELAJARAN DARING TERHADAP HASIL BELAJAR SISWA MI MUHAMMADIYAH 5 SURABAYA
}

\author{
${ }^{1}$ Yulia Khurriyati, 2 Fajar Setiawan, ${ }^{3}$ Lilik Binti Mirnawati \\ 1yulia.khurriyati-2018@fkip.um.surabaya.ac.id,2fajarsetiawan@fkip.um-surabaya.ac.id, \\ 3lilikbintimirnawati@fkip.um-surabaya.ac.id \\ 1,2,3Universitas Muhammadiyah Surabaya
}

\begin{abstract}
ABSTRAK
Penelitian ini bertujuan untuk mengetahui dampak selama pembelajaran daring terhadap kenaikan hasil belajar siswa dibandingkan dengan saat pembelajaran tatap muka di sekolah MI Muhammadiyah 5 Surabaya, khususnya pada kelas yang diampu oleh penulis. Metode penelitian yang dipakai dalam penelitian ini adalah metode penelitian kualitatif diskriptif dengan menggunakan teknik pengumpulan data yaitu teknik wawancara. Penulis menggunakan teknik wawancara dengan mengumpulkan informasi dari 5 orang walimurid dan 5 siswa dari kelas yang diampunya. Berdasarkan dari wawancara bersama 5 walimurid dan 5 siswa tersebut, ditemukan bahwa siswa-siswa tersebut mengalami kenaikan hasil belajarnya selama pembelajaran daring dibandingkan dengan hasil belajar saat tatap muka. Penyebab dari kenaikan hasil belajar siswa tersebut adalah siswa banyak mendapat bantuan menyeluruh dan langsung dari orang tua, saudara atau tetangga yang mendampingi siswa saat melakukan pembelajaran daring. Namun begitu, juga ditemukan bahwa dampak pendampingan daring seperti itu akan berakibat negatif terhadap perkembangan siswa kedepannya. Dampak negatif terhadap perkembangan siswa yaitu siswa lebih tidak peduli atau terkesan meremehkan terhadap setiap tugasnya. Selain itu, siswa juga akan lebih banyak menggantungkan diri terhadap bantuan orang lain sehingga menjadikan dirinya pribadi yang kurang mandiri. Pada akhirnya kondisi siswa yang kurang mandiri tersebut juga akan sering membuat walimurid kesulitan saat mengarahkan siswa untuk menyelesaikan setiap tugas dan tanggungjawab di sekolahnya.
\end{abstract}

Kata kunci: pembelajaran daring, hasil belajar

\section{THE IMPACT OF ONLINE LEARNING ON LEARNING OUTCOMES}

\section{IN MI MUHAMMADIYAH 5 SURABAYA}

\begin{abstract}
This study aims to see the impact during learning on the increase in student learning outcomes compared to face-to-face learning at the school of MI Muhammadiyah 5 Surabaya, especially in the class managed by the author. The research method used in this research is a descriptive qualitative research method using data techniques namely interview techniques. The author uses the interview technique by collecting information from 5 parents and 5 students from the class she is teaching. Based on those interviews, it was found that these students experienced an increase in their learning outcomes during courageous learning compared to their face-to-face learning outcomes. The reason for the increase in student learning outcomes; is the comprehensive and direct assistance from parents, relatives, or neighbors who accompany students during learning. However, the impact of those learning harms the future students' development that is the students seem to underestimate their task. Besides, the students will also depend more on the help of others so that they make themselves rely on. The condition of the students who rely on, will make it difficult for the students to complete each task and responsibility in their school.
\end{abstract}

Keywords: online learning, learning outcomes 


\section{PENDAHULUAN}

Indonesia merupakan salah satu negara yang tercatat terpapar virus pada sekitar pertengahan bulan Maret 2020. Ada 2 orang yang terindikasi positif menderita Covid19 dikonfirmasikan langsung oleh Presiden Joko Widodo pada tanggal 2 Maret 2020. Kasus ini terdeteksi setelah ada seorang warga Jepang yang dinyatakan terjangkit virus corona setelah meninggalkan Indonesia dan tiba di Malaysia. Setelah ditindaklanjuti dan dilakukan penelusuran, Orang Jepang yang terdeteksi terkena virus corona tersebut ke Indonesia sempat bertemu dengan dua warga Indonesia, yaitu ibu 64 tahun dan putrinya 31 tahun. Mereka diketahui sempat melakukan dansa bersama di salah satu klub di Jakarta (Ihsanuddin, 2020). Sejak saat itu pemerintah melakukan upayaupaya kebijakan untuk menghadapi penyebaran virus ini lebih lanjut, seperti isolasi, social and physical distancing hingga pembatasan bisa berskala besar (PSBB).

Akibat Kondisi Covid-19, beberapa instansi menerapkan Work from Home (WFH) atau bekerja dari rumah, termasuk juga lembaga atau instansi pendidikan. Pemerintah memberi kebijakan bagi setiap sekolah untuk melakukan pembelajaran secara daring, yakni dengan menggunakan gadget (laptop atau HP) untuk mengakses Website atau Link pembelajaran daring seperti Google Form, Microsoft 365, Google Classroom, dll. Kebijakan pelaksanaan daring bagi siswa telah ditetapkan oleh pemerintah Indonesia melalui Surat Edaran Kementerian Pendidikan dan Kebudayaan Indonesia Nomor 4 Tahun 2020 tentang Pelaksanaan Pendidikan Dalam Masa Darurat Covid-19 dan diperkuat dengan Surat Edaran Sesjen nomor 15 tahun 2020 tentang Pedoman Pelaksanaan BDR selama darurat Covid-19 yang menyatakan bahwa tujuan Belajar Dari Rumah (BDR) adalah untuk memenuhi standard pendidikan melalui pemanfaatan teknologi informasi dengan menggunakan perangkat komputer atau gadget yang saling terhubung antara siswa dan guru (Astini, 2020). Hal ini masih dilakukan bahkan sampai memasuki bulan Agustus 2020, dikarenakan situasi penyebaran pandemi corona Covid-19 di Indonesia masih belum menunjukkan tanda-tanda melandai bahkan kasusnya terus mengalami peningkatan.

Menindaklanjuti surat edaran tersebut, MI Muhammadiyah 5 Surabaya melakukan pembelajaran dari rumah dengan memberikan siswa tugas-tugas melalui 
media seperti website atau link yang dibuat dari Microsoft Form dan Google Form. Selama pembelajaran daring berlangsung, siswa mengirimkan tugas-tugasnya bisa langsung melalui beberapa program di handphone seperti WhatsApp atau Google Classroom. Namun demikian, penulis menemukan fakta bahwa hasil belajar siswa selama pembelajaran daring mengalami peningkatan pesat dibandingkan dengan pembelajaran tatap muka. Hal tersebut didapat penulis dari rata-rata perolehan nilai siswa yang mendapat nilai di atas KKM sebelum dan sesudah pembelajaran daring dilakukan. Misalnya, sebelum pembelajaran daring atau masih melakukan pembelajaran tatap muka, ada sekitar 5-10 siswa dari 24 siswa yang mendapatkan nilai di atas KKM namun ketika sudah melakukan pembelajaran daring, ada sekitar 20 siswa dari 24 siswa yang mendapatkan nilai di atas KKM. Data ini bisa kita bandingkan dari kenaikan yang cukup tinggi dari nilai rata - rata pengetahuan/KI3 di semester 1 (masih dalam pembelajaran tatap muka) dengan nilai rata- rata pengetahuan/KI3 siswa di semester 2 (daring). Berdasarkan nilai yang diperoleh siswa pada semester I dengan semester II, penulis telah mengetahui bahwa ada kenaikan jumlah nilai KI3 dari seluruh mata pelajaran yaitu 1.711 dan rata2 nilai KI3 dari seluruh mata pelajaran yaitu 110,65. Kondisi tersebut mendorong penulis untuk mengetahui apa yang menyebabkan banyak siswa bisa mendapatkan nilai di atas KKM dibandingkan nilai saat siswa melakukan pembelajaran langsung atau tatap muka. Hal tersebut membuat penulis melakukan penelitian dengan tujuan untuk menemukan penyebab peningkatan hasil belajar siswa saat melakukan pembelajaran melalui online daripada pembelajaran melalui tatap muka.

\section{METODE PENELITIAN}

Penelitian ini menggunakan metode pendekatan kualitatif. Menurut Sugiyono (2016) metode penelitian kualitatif adalah metode penelitian yang digunakan untuk meneliti pada kondisi obyek yang alamiah dan dilandaskan pada filsafat postpositivisme, dimana peneliti adalah sebagai instrument kunci atau penentu dalam pengambilan data sehingga tujuan penelitian dapat tercapai. Penelitian ini dilakukan penulis hanya di lingkungan MI Muhammadiyah 5 Surabaya, khususnya pada kelas yang diampu oleh penulis yaitu kelas 4. Dari kelas yang diampunya, penulis hanya mengambil sample wawancara dari 5 orang walimurid dan 5 siswa. Sampel data dari 5 siswa yang diambil 
oleh penulis tersebut dikarenakan 5 siswa tersebut memiliki kedua orang tua yang aktif bekerja dari pagi hingga malam sehingga memiliki keterbatasan waktu dalam pendampingan belajar putra/putrinya, nilai siswa yang berada di atas KKM saat pembelajaran daring dan kondisi ekonomi dari siswa yang terbatas. Kondisi ini dianggap penulis sudah dapat mewakili keseluruhan dari siswa-siswanya di kelas karena sebagian besar orang tua di kelas yang diampu oleh penulis adalah kedua orang tuanya sibuk di dalam pekerjaannya.

Adapun teknik yang dilakukan oleh penulis dalam pengumpulan data adalah dengan teknik wawancara. Menurut Rowley (2012), wawancara merupakan suatu teknik pengumpulan data yang dapat dilakukan secara terstruktur, semi terstruktur dan tidak terstruktur. Penjelasan dari Rowley disempurnakan dengan penjelasan dari Winardi (2018), wawancara tidak terstruktur lebih mirip percakapan biasa, berbeda dengan wawancara jenis lain yang sering dianggap sebagai percakapan terkendali yang lebih menitikberatkan pada kepentingan sipewawancara. Hal ini dapat dipahami bahwa penggunaan salah satu teknik wawancara tersebut akan membantu penulis menemukan tujuan penelitiannya. Teknik pelaksanaan wawancara penulis yaitu melalui tahap-tahap sebagai berikut: pertama, melakukan wawancara tidak terstruktur dengan walimurid saat penulis melakukan penerimaan hasil belajar siswa secara langsung. Setelah mendapatkan informasi dari walimurid, penulis melakukan konfirmasi satu persatu dengan siswa melalui video call atau telpon secara bergantian dengan siswa yang bersangkutan.

Dalam pelaksanaan wawancara, penulis melakukan jenis wawancara bebas terpimpin. Menurut Kurniawan (2020), Dalam wawancara bebas terpimpin, pewawancara mengombinasikan wawancara bebas yaitu bebas bertanya kepada responden namun masih berhubungan dengan data-data yang diinginkan dipadukan dengan wawancara terpimpin, yang dalam pelaksanaannya pewawancara sudah membawa pedoman tentang apa-apa yang ditanyakan secara garis besar. Melalui teknik wawancara bebas terpimpin, Penulis berharap bisa lebih mudah mendapatkan informasi dari walimurid dan siswa yang diwawancarainya. Selain itu Penulis juga lebih fleksible dan leluasa untuk mengembangkan pertanyaan yang ingin diajukan kepada walimurid dan siswanya. Oleh karena itu, Penulis akan lebih cepat mendapatkan informasi yang diinginkan. 
Data yang telah diperoleh selanjutnya dianalisis dengan teknik analisis data kualitatif. Menurut Miles, Huberman, \& Sadana (2013) ada 3 kegiatan dalam analisis data yang meliputi :

\section{Reduksi Data}

Menurut Miles, Huberman, \& Sadana (2013), "Pengurangan data atau reduksi data mengacu pada proses memilih, memfokuskan, menyederhanakan, mengabstraksikan dan mengubah data yang muncul dalam catatan lapangan atau transkripsi tertulis". Berdasarkan pernyataan tersebut dapat dipahami bahwa dilakukannya reduksi data, akan diperoleh data yang lebih jelas dan data tersebut akan menjadi informasi yang lebih bermakna. Data yang diperoleh dari penelitian ini semula berupa data mentah yang berasal dari catatan lapangan, dan wawancara bebas terpimpin. Data-data tersebut akan direduksi untuk memperoleh informasi yang lebih bermakna sesuai tujuan penelitian. Penelitian ini dilakukan untuk mengetahui penyebab peningkatan hasil belajar siswa yang diteliti saat melakukan pembelajaran melalui online daripada pembelajaran melalui tatap muka.

2. Penyajian Data

Tampilan data melibatkan hasil dari reduksi data seperti matriks, grafik, bagan dan jaringan. Berdasarkan pernyataan tersebut, penyajian data dapat dilakukan dalam bentuk tabel maupun grafik, data akan lebih mudah dipahami. Dalam penelitian ini, data hasil catatan lapangan dan wawancara yang telah direduksi akan disajikan dalam bentuk diskriptif. Data yang mencerminkan hasil belajar siswa sebelum dilakukan pembelajaran daring dengan sesudah pembelajaran daring akan disajikan dalam bentuk tabel.

\section{Penarikan Kesimpulan}

Penarikan kesimpulan dalam analisis data wawancara dapat dilakukan lewat beberapa teknik, antara lain adalah penggunaan analisis isi dan analisis tematik. "Proses analisis isi akan memisahkan data dari konteks wawancara untuk analisis dan menempatkannya dalam file terpisah, membentuk kategori untuk konseptualisasi dan analisis lebih lanjut." Berdasarkan pernyataan tersebut, dapat dipahami bahwa pengambilan data tidak memiliki batasan yang bisa diambil dari wawancara karena setiap hasil wawancara berkontribusi untuk proses analisis selanjutnya. 
Penggunaan analisis berikutnya adalah analisis tematik. "Tema mungkin secara eksplisit akan nampak atau bisa juga tersembunyi di balik teks. Tema dapat ditemukan menggunakan teknik interpretatif seperti analisis metafora atau dengan mempelajari apa yang tersirat." Berdasarkan pernyataan ini dapat dipahami bahwa penarikan kesimpulan dilakukan setelah adanya pemaknaan data yang disajikan ke dalam sebuah pernyataan. Dengan menelaah intisari dari berbagai data yang disajikan akan diperoleh kesimpulan bagi penelitian yang dilakukan. Penarikan kesimpulan ini dilakukan untuk menjawab permasalahan yang ingin diketahui oleh peneliti. Selanjutnya, data yang telah diperoleh peneliti digabungkan dengan review data hasil belajar siswa sebelum melakukan pembelajaran daring dengan setelah melakukan pembelajaran daring untuk mensikronkan hipotesa peneliti dengan hasil wawancara.

\section{HASIL DAN PEMBAHASAN}

\section{Hasil Penelitian}

Pelaksanaan pembelajaran daring (dalam jaringan) selama pandemi mengakibatkan pergeseran peran antara guru dan orang tua atau orang yang mendampingi siswa selama pembelajaran daring tersebut. Hal ini bisa diartikan bahwa orang tua atau walimurid selain menjadi orang tua yang sebenarnya di rumah, juga berperan sebagai pendamping siswa belajar di rumah atau berperan menjadi wali kelasnya di rumah. Peran serta orang tua dalam pembelajaran siswa baik dalam pemahaman materi juga penanaman karakter akan sangat menentukan kesuksesan siswa dalam setiap pembelajarannya selama masa pandemi berlangsung. Namun, dalam peran serta orang tua di setiap pembelajaran siswa tersebut ada yang mampu memberi pengaruh positif ataupun negatif terhadap karakter ataupun hasil belajar siswa.

Dalam hal ini, penulis memperoleh beberapa temuan selama pembelajaran daring tersebut yaitu penyebab dari hasil belajar siswa yang selalu mencapai KKM atau nilainya selalu bagus pada hampir setiap tugas yang diberikan oleh gurunya dibandingkan dengan hasil belajar siswa selama pembelajaran tatap muka di sekolah. Penulis menemukan penyebab tersebut tanpa terencana saat melakukan wawancara dengan 5 orang walimurid dan 5 siswa di kelas yang diampu penulis. Tahap wawancara yang dilakukan oleh penulis adalah dengan mengajukan pertanyaan yang sama kepada narasumber yang berbeda, kemudian mengkonfirmasi jawaban tersebut dengan 
putra/putri dari narasumber. Berikut ini adalah pertanyaan yang diajukan oleh penulis kepada narasumber :

1. Bagaimana pendapat walimurid tentang pembelajaran daring yang telah dilakukan?

2. Apakah ada kesulitan selama pembelajaran daring dan upaya apa yang dilakukan oleh walimurid untuk menyelesaikan kesulitan tersebut?

Berdasarkan kedua pertanyaan tersebut, penulis mendapatkan berbagai macam respon jawaban. Pada wali murid pertama yang putrinya berinisial CA menceritakan, "Selama pembelajaran daring ini, Ustadzah. Saya mengalami banyak kesulitan mendampingi anak saya karena waktu mendampinginya terbatas. Saya harus segera berangkat kerja sedangkan ayahnya ada dinas di luar kota dan untuk pulang ke rumah tidak bisa ditentukan waktunya. Jadi...saat anak saya CA mengerjakan tugasnya terlalu lama, langsung saya beri tau jawabannya atau tugasnya sebagian saya langsung kerjakan saja, Us. Biar cepat selesai ".

Dari penjelasan wali murid dari siswa CA tersebut, penulis mendapatkan informasi bahwa walimurid dari CA mengalami kesulitan waktu dalam pendampingan karena harus segera bekerja, sedangkan ayahnyapun berada di luar kota. Hal itu mengakibatkan walimurid dari siswa berinisial CA berinisiatif langsung membantu putrinya dengan instan/ langsung yaitu dengan cara memberi tau jawabannya atau mengerjakan tugas siswa tersebut yang seharusnya menjadi tanggungjawab putrinya. Kemudian, saat dilakukan konfirmasi lanjutan terhadap siswa CA saat melakukan video call, siswa CA menjelaskan, "Iya maaf Ustadzah, CA kalau sedang tidak ingin mengerjakan, suka malas menyelesaikan. Jadi, Bunda sering bantu, katanya biar cepat selesai. Lagipula Bunda juga sering terburu-buru saat mengajari aku".

Dari penjelasan siswa CA, penulis dapat memahami bahwa siswa CA memiliki keadaan hati yang sering berubah. Keadaan hati yang suka berubah tersebut membuat siswa CA memilik semangat belajar rendah. Hal ini didukung dengan kondisi lingkungannya yang membuat dia terpaksa harus segera menyelesaikan tugasnya dengan cepat.

Berdasarkan hasil wawancara dari walimurid CA ditambahkan dengan wawancara kedua dari Walimurid FZ, yang mana saat di kelas diketahui penulis bahwa siswa FZ memiliki sikap yang kurang memperhatikan dalam kedisiplinan pengumpulan tugasnya. Namun saat pembelajaran daring berlangsung, walimurid FZ bercerita, "FZ suka sekali 
saat pembelajaran daring karena lebih mudah dan nyaman. FZ menceritakan bahwa akan ada banyak bantuan dari mama atau kakak saat dirinya tidak bisa atau sedang malas mengerjakan." Saat penulis melakukan komunikasi langsung melalui Video Call dengan siswa FZ yang dikenal dengan siswa memiliki kepercayaan diri dan ego tinggi di kelas, awalnya belum mau membenarkan penjelasan dari mamanya saat penulis menanyakan apakah tugas yang dikumpulkan adalah hasil sendiri atau bantuan dari orang tua atau orang lain. Namun setelah berdiskusi cukup santai dengan siswa tersebut, akhirnya siswa menceritakan bahwa apa yang dilaporkan mamanya adalah benar.

Sedikit berbeda dengan hasil wawancara ke tiga dari walimurid ZF, yang mengatakan bahwa putranya hanya dibantu mengerjakan saat melakukan pembelajaran tugas praktek atau proyek yang berhubungan dengan keterampilan saja. Hal ini dilakukan karena saat mengerjakan tugas praktek atau proyek, putranya ZF membutuhkan waktu yang lebih lama jika harus mengerjakan sendiri sedangkan tugas praktek atau proyek biasanya diberikan saat menjelang akhir pekan. Berlawanan dengan hal itu, keluarganya harus berkunjung ke rumah orang tuanya di luar kota. Jadi, menurut walimurid ZF penyelesaian tugas praktek dan proyek harus segera diselesaikan. Saat siswa Zf ditanyai melalui komunikasi Video Call, Siswa ZF langsung bercerita dengan jujur kebenaran dari cerita mamanya.

Selanjutnya wawancara keempat datang dari walimurid JN yang bercerita bahwa putrinya saat melakukan pembelajaran daring sangat enggan karena menjenuhkan tidak bisa berjumpa langsung dengan teman dan ustadz-ustadzahnya di sekolah. Akibatnya, saat terkadang siswa JN merasa jenuh, orang tuanya atau kakak kandungnya sering membantu dirinya dengan menyelesaikan setiap tugas yang wajib diselesaikan pada saat itu. Penjelasan dari walimurid JN, segera dibenarkan oleh siswa JN sendiri saat melakukan komunikasi secara virtual lewat video whats up dengan penulis sebagai wali kelasnya.

Berdasarkan wawancara terakhir, ada walimurid dari $\mathrm{Rr}$ yang bercerita bahwa tugas-tugas yang sulit dikerjakan putranya seringkali dikerjakan langsung oleh ayah atau dirinya sendiri. Hal ini disebabkan oleh bergilirnya penggunaan HP antara siswa Rr dan adiknya yang juga bersekolah sama. Kondisi tersebut juga dipengaruhi oleh ayah yang bekerja di luar kota dan ibu yang harus segera berdagang dengan menggunakan 
HP yang dipakai siswa sehingga siswa Rr dan adiknya harus segera menyelesaikan tugasnya lebih cepat. Siswa Rr pun tidak mengelak penjelasan dari mamanya saat dilakukan komunikasi langsung secara virtual dengan penulis.

Selain dari wawancara dengan wali murid dan siswa tersebut, penulis juga menemukan fakta sendiri bahwa saat siswa melakukan pembelajaran daring secara online. Orang tua yang melihat anak - anaknya mengalami kesulitan saat menjawab langsung atau melakukan setoran hafalan melalui rekam video, juga seringkali diberi arahan atau kode - kode dari orang tua sendiri atau saudara yang sedang mendampingi anak tersebut belajar dengan cara membelakangi layar kamera. Hal ini tampak langsung saat siswa mengalami kesulitan menjawab atau melanjutkan setoran hafalannya, pandangan siswa selalu mencoba mencari bantuan dari orang yang ada di sekitarnya dan saat dirinya sudah mendapatkannya, anak akan lancar kembali menghafalkan atau menjawab.

Berdasarkan dari wawancara dengan walimurid dan siswa tersebut serta juga temuan penulis sendiri saat melakukan evaluasi dari rekam video, secara umum ditemukan penyebab hasil belajar siswa yang mengalami kenaikan atau banyak yang mencapai KKM selama pembelajaran daring daripada saat pembelajaran tatap muka yaitu ada peran serta orang tua yang berlebihan dalam menyelesaikan setiap tugas siswa di rumah. Hal ini dipengaruhi oleh beberapa faktor yaitu faktor dari orang tua, siswa sendiri atau sarana dan prasarana yang terbatas.

Faktor dari orang tua misalnya orang tua kurang bersabar dan telaten dalam membantu siswa melewati setiap proses tahapan yang harus dilalui siswa, orang tua juga mempunyai kesibukan yang padat di luar rumah sehingga saat mendampingi putra/putrinya di rumah juga terbatas. Hal ini mengakibatkan orang tua terburu - buru saat mendampingi putra/putrinya belajar di rumah sehingga orang tua berpikir jika membantu dengan langsung dengan memberi jawabannya saja akan mempermudah diri dan putra/putrinya saat itu. Kemudian faktor lainnya adalah dari siswa itu sendiri, bisa berupa perubahan interest yang cepat berubah dari yang berminat, tiba - tiba malas mengerjakan atau memang siswa tersebut merasa malas untuk menyelesaikan setiap tugas yang diberikan oleh gurunya. Wali murid yang kurang bersabar terhadap sikap putra/putrinya tersebut, akan langsung mengambil alih tugasnya supaya putra/putrinya tetap tercatat telah menyelesaikan tugasnya dan mendapat hasil yang 
terbaik. Kemudian, faktor yang terakhir adalah ketersediaan sarana dan prasarana walimurid dan siswa yang bersangkutan di rumah, seperti HP, laptop dan kuota serta jaringan internet yang lancar. Sarana dan prasarana selama pembelajaran daring ini, juga akan menentukan keberhasilan siswa termasuk emosi walimurid saat mendampingi putra/ putrinya belajar di rumah.

Berikut ini adalah daftar tabel perbandingan nilai tiap siswa dari kelas 4 yang diampu oleh penulis pada semester I dengan semester II. Tabel ini digunakan penulis sebagai landasan data sebelum melakukan wawancara:

Tabel 1. Perbandingan Hasil Belajar Siswa di Semester I dan II

\begin{tabular}{clcccc}
\hline No & $\begin{array}{c}\text { Nama } \\
\text { Siswa }\end{array}$ & Jml. Sem. I & Jml. Sem. II & Rerata Sem I & Rerata Sem. II \\
\hline 1 & Siswa Ak & 1292 & 1338 & 86,13 & 88,79 \\
2 & Siswa Ah & 1326 & 1361 & 88,4 & 90,71 \\
3 & Siswa Az & 1246 & 1337 & 83,07 & 89,64 \\
4 & Siswa Ar & 1321 & 1360 & 88,07 & 90,21 \\
5 & Siswa Ap & 1186 & 1324 & 79,07 & 87,93 \\
6 & Siswa Ae & 1247 & 1290 & 83,13 & 86,36 \\
7 & Siswa Ay & 1357 & 1264 & 90,47 & 95 \\
8 & Siswa By & 1337 & 1377 & 89,13 & 91,57 \\
9 & Siswa Ca & 1186 & 1372 & 79,07 & 91,14 \\
10 & Siswa Df & 1213 & 1311 & 80,87 & 87 \\
11 & Siswa Fz & 1213 & 1305 & 80,87 & 86,86 \\
12 & Siswa Jn & 1180 & 1344 & 78,67 & 89,14 \\
13 & Siswa Js & 1422 & 1308 & 94,8 & 96,07 \\
14 & Siswa Az & 1373 & 1421 & 91,53 & 94,57 \\
15 & Siswa Zf & 1169 & 1398 & 77,93 & 93,36 \\
16 & Siswa Mr & 1164 & 1212 & 77,6 & 80,86 \\
17 & Siswa Mw & 1215 & 1296 & 81 & 86,43 \\
18 & Siswa Nr & 1315 & 1326 & 87,67 & 88 \\
19 & Siswa An & 1251 & 1277 & 83,4 & 85,14 \\
20 & Siswa Rr & 1197 & 1341 & 79,8 & 89,21 \\
21 & Siswa Tn & 1309 & 1342 & 87,27 & 89,29 \\
22 & Siswa Wa & 1284 & 1285 & 85,6 & 85,71 \\
23 & Siswa Ma & 1174 & 1353 & 78,27 & 89,79 \\
24 & Siswa Ah & 1210 & 1356 & 80,67 & 90,07 \\
\hline & JUMLAH & $\mathbf{3 0 1 8 7}$ & $\mathbf{3 1 8 9 8}$ & $\mathbf{2 . 0 1 2 , 4 9}$ & $\mathbf{2 . 1 4 2 , 8 6}$ \\
\hline & & & & &
\end{tabular}




\section{Pembahasan}

Berdasarkan wawancara bersama 5 orang walimurid dan 5 siswa yang ada pada kelas 4, Ada beberapa faktor yang menyebabkan siswa yang memiliki nilai rata-rata sedang selama pembelajaran tatap muka, kemudian mengalami kenaikan pada saat pembelajaran daring berlangsung yaitu banyak mendapat bantuan penyelesaian tugas dari orang tua atau saudara atau orang yang sedang mendampinginya belajar. Hal ini disebabkan oleh 2 faktor yaitu mulai dari durasi waktu yang dibutuhkan siswa dalam menyelesaikan tugas masih kurang, sarana dan prasarana kurang memadai seperti HP yang harus digunakan bergantian. Faktor tersebut mengakibatkan semangat siswa yang terkadang naik dan juga terkadang turun saat melakukan pembelajaran daring.

Proses pendampingan orang tua selama masa pandemi ini memang memiliki peranan yang sangat penting terhadap kesuksesan belajar siswa. Namun hal ini bukan berarti akan menggantikan tanggungjawab yang seharusnya dilakukan oleh siswa sendiri. Tugas orang tua hanyalah sebagai pengarah dan pembimbing dalam proses pendampingan tersebut. Hal ini sesuai dengan pernyataan dari Winingsih pada Cahyati (2020), tentang 4 peran orang tua dalam pembelajaran jarak jauh (PJJ) yang terdiri dari 1. Orang tua memiliki peran sebagai guru di rumah, yang di mana orang tua dapat membimbing anaknya dalam belajar secara jarak jauh dari rumah. 2. Orang tua sebagai fasilitator, yaitu orang tua sebagai sarana dan pra-sarana bagi anaknya dalam melaksanakan pembelajaran jarak jauh. 3. Orang tua sebagai motivator, yaitu orang tua dapat memberikan semangat serta dukungan kepada anaknya dalam melaksanakan pembelajaran, sehingga anak memiliki semangat untuk belajar, serta memperoleh prestasi yang baik. 4. Orang tua sebagai pengaruh atau director. Dari pernyataan Winingsih tersebut dapat dipahami bahwa orang tua hanya sebagai pembimbing, penyedia kebutuhan, penyemangat dan memberi pengaruh yang baik, disini orang tua sebagai contoh karakter yang baik bagi anaknya. Jika sikap wali murid dalam membimbing putra/putrinya masih dilakukan sama yaitu menggantikan semua tanggungjawab tugas yang harus diselesaikan putra/putrinya maka akan mampu membawa pengaruh buruk atau negatif terhadap kebiasaaan putra/putrinya di masa yang akan datang seperti kurang mandiri, kurang kepercayaan diri terhadap hasil kerjanya dan lebih tidak memperdulikan tugas-tugasnya jika tidak ada pendampingan. 
Lain halnya jika walimurid bisa menempatkan dirinya sebagai pendamping belajar yang bisa diajak saling bertukar pikiran atau hanya mengarahkan apa yang sebaiknya dilakukan putra/putrinya saat menemukan kesulitan. Walimurid akan secara sengaja mencetak putra/putrinya berpikir lebih kritis dan logis serta akan memiliki sikap mandiri dan penuh percaya diri. Sehingga kebiasaan yang telah dicontohkan oleh walimurid akan sangat membantu putra/putinya dalam menyelesaikan setiap permasalahan atau kesulitan yang akan dihadapinya. Selain itu hal positif yang bisa diambil adalah siswa akan lebih memiliki keterikatan emosi dengan kedua orang tuanya selama masa pembelajaran daring berlangsung dan walimurid akan lebih mudah memantau perkembangan belajar siswa secara periodik. Temuan Penulis tersebut telah dijelaskan oleh Ikhsan (2015), bahwa pengaruh orang tua sangat menentukan arah perkembangan masa depan anak-anak mereka terutama sifat orang tua dan keadaan mereka. Sifat orang tua seperti orang tua bersikap, memandang, memikirkan dan memperlakukan anak.

\section{SIMPULAN}

Berdasarkan temuan penulis dari wawancara dengan walimurid dan siswa di kelas yang diampunya serta temuan penulis sendiri saat melakukan evaluasi siswa dari setor hafalannya, penulis menyimpulkan bahwa penyebab dari meningkatnya hasil belajar siswa yang biasanya memiliki nilai kurang dari standar KKM saat pembelajaran tatap muka, ternyata selama pembelajaran daring dapat mencapai banyak nilai di atas KKM. Hal ini disebabkan oleh beberapa faktor yaitu mulai dari durasi waktu yang dibutuhkan siswa dalam menyelesaikan tugas, sarana dan prasarana seperti HP yang harus digunakan bergantian hingga semangat siswa yang naik turun saat melakukan pembelajaran daring, kebutuhan dan kondisi dari tiap siswa yang berbeda. Hal ini mendorong walimurid untuk tetap mengusahakan anaknya supaya tetap bisa mengikuti tugas yang diberikan sekolah. Usaha walimurid yang terlalu memberikan kemudahan atau memberi bantuan pada siswa dalam menyelesaikan tugas berakibat negatif pada perkembangan siswa kedepannya. Adapun akibat negatif yang ditemukan penulis diantaranya siswa akan lebih menggantungkan diri pada orang lain atau orang tuanya dalam setiap penyelesaian tugasnya, siswa lebih mengacuhkan tugas-tugasnya jika tidak 
ada pendampingan, dan siswa akan kurang percaya diri dalam setiap penyelesaian tugas-tugasnya.

Penulis menyarankan sebaiknya orangtua atau siapapun yang sedang mendampingi anak dalam melakukan pembelajaran daring, hanya berperan sebagai pendamping yang mengarahkan saja bukan menggantikan tanggungjawab anak dalam menyelesaikan tugas - tugasnya. Dengan menggantikan setiap tanggungjawab anak, maka secara tidak langsung anak akan lebih menyepelekan dengan setiap tugas yang dibebankan. Akibat selanjutnya, anak akan menjadi pribadi yang kurang mandiri karena akan selalu mengandalkan orang lain saat dirinya mengalami kesulitan atau sedang malas melakukan apapun.

Penulis menyarankan bagi siswa supaya lebih percaya diri dalam menyelesaikan setiap tanggungjawab yang seharusnya dilakukan. Hal ini sangat berguna bagi perkembangan siswa sendiri kedepannya. Siswa akan lebih yakin dalam menyelesaikan setiap kendala yang dihadapi. Selain itu siswa akan lebih mandiri dan tidak mudah bergantung pada orang lain. Kemandirian siswa tersebut, juga akan membantu walimurid dalam memantau perkembangan belajar siswa lebih mudah.

Terakhir dan yang tidak kalah pentingnya, penulis juga menyarankan kepada guru bisa memberikan waktu yang lebih luang dan fleksible bagi siswa dalam penyelesaian setiap tugas yang diberikan dari sekolah seperti saat waktu pengumpulan dan saat pengerjaan tugasnya. Guru juga bisa melakukan pendampingan secara langsung kepada siswa yang terlihat benar-benar membutuhkan contohnya siswa yang benar-benar tidak mendapatkan pendampingan dari orng tua bisa diajak untuk belajar di Guru juga bisa berkoordinasi dengan sekolah untuk membuat program khusus selama pembelajaran daring berlangsung. Sinergi yang baik antara walimurid, sekolah dan siswa sangat dibutuhkan sekali dalam pembelajaran daring saat ini. Kepercayaan satu sama lain antara walimurid, siswa dan sekolah terutama guru juga akan terbentuk jika setiap pihak juga menyadari betapa pentingnya kerjasama yang dilandasi dengan kejujuran dari masing-masing pihak. Diharapkan dengan adanya sinergi yang baik tersebut, tujuan pendidikan sesungguhnya bisa tercapai dan siswa tetap mampu mengembangkan potensinya meskipun pembelajaran tidak dilakukan melalui tatap muka langsung. 


\section{DAFTAR PUSTAKA}

Astini, N. K. S. (2020). Pemanfaatan teknologi informasi dalam pembelajaran tingkat sekolah dasar pada masa pandemi Covid-19. Jurnal Lampuhyang, 11(2), 13-25.

Cahyati, N., \& Kusumah, R. Peran orang tua dalam menerapkan pembelajaran di rumah saat pandemi Covid 19. Jurnal Golden Age, 4(1), 152-159.

Davidson, H. (2020). Covid-19 case happened in November, China government records show - report. Maret 2020. The Guardian. ISSN 0261-3077.

Fuad Ikhsan. (2015). Dasar-Dasar Kependidikan. Jakarta: Rieneka Cipta.

Gunawan, H. (2017). Dasar-Dasar Metodologi Penelitian Pendidikan. Bandung: Fakultas Tarbiyah dan Keguruan UIN Sunan Gunung Djati.

Ihsanuddin. (2020). Fakta lengkap kasus pertama virus Corona di Indonesia. Kompas. Diterima dari https://nasional.kompas.com/read/2020/03/03/06314981/fakta-lengkapkasus-pertama-virus-corona-di-indonesia?page=all.

Bastian, I., Winardi, R. D., \& Fatmawati, D. (2018). Metoda Wawancara. Yogyakarta: Fakultas Ekonomika dan Bisnis Universitas Gadjah Mada.

Jamaluddin, D., Ratnasih, T., Gunawan, H., \& Paujiah, E. (2020). Pembelajaran daring masa pandemik Covid-19 pada calon guru: hambatan, solusi dan proyeksi. LP2M.

Kurniawan, A. (Agustus 2020). Pengertian wawancara. Guru Pendidikan. Diterima dari https://www.gurupendidikan.co.id/pengertian-wawancara.

Miles, M. B., Huberman, A. M., \& Saldana, J. (2013). Qualitative data analysis. Thousand Oaks: SAGE Publications.

Rowley, J. (2012). Conducting research Interviews. Management research review.

Sugiyono. (2008). Metode penelitian kualitatif. Bandung: Alfabeta. 